\title{
Blended Learning Strategies of Telegram-Assisted Learning Towards Student Mathematics Learning Results Reviewed from Learning Style
}

\author{
Kadek Suryati' ${ }^{1}$ I Gede Adnyana ${ }^{2}$ \\ 1Informatics Engineering Program, STMIK STIKOM Indonesia, Indonesia \\ ${ }^{1}$ Computer System Program, STMIK STIKOM Indonesia, Indonesia \\ 1kadek.suryati@stiki-indonesia.ac.id, 2adnyana@stiki-indonesia.ac.id
}

\section{Article History:}

Received : 17-06-2020

Revised 1 : 28-06-2020

Revised 2 : 14-09-2020

Accepted : 14-09-2020

Online : :03-10-2020

\section{Keyword:}

Blended learning strategy;

Telegram;

Learning style;

Mathematics learning results;

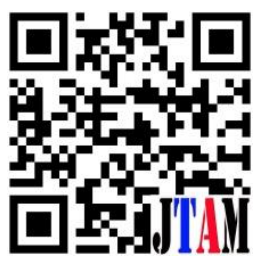

\section{ABSTRACT}

The research aims to describe the influence of telegram-assisted blended learning strategies on mathematics learning outcomes in terms of learning styles. This research is a quasi-experimental research using $2 \times 3$ factorial design. The respondents taken is the second semester students majoring in informatics engineering at the STMIK STIKOM Indonesia campus. The sampling procedure in this study was a random sampling technique that was started by carrying out the equivalency test of 4 classes taken using the one-way ANOVA test. After that randomly selected, two classes as an experimental class and two classes as a control class. To get instruments that have validity before use, questionnaires and tests are first tested and validated by experts who are experts in their fields. Normality and homogeneity tests are needed as a prerequisite before analyzing the data. The method used to analyze data is twoway ANOVA. The results showed that (1) student mathematics learning outcomes taught with telegram-assisted blended learning strategies were better than conventional mathematics learning outcomes of students taught, (2) the effect of telegraph-assisted blended learning strategies on student mathematics learning outcomes in learning styles. Based on the results of the research that has been carried out, it is recommended that further researchers or educators be able to develop a blended learning strategy as a way to convey learning material so that they can pay more attention to the learning styles of each student and can develop telegrams with more attractive features so that the telegram becomes one of online application for learning media.

\begin{tabular}{cc} 
dol $/$ Crossref & (c) (i) () \\
https://doi.org/10.31764/itam.v4i2.2438 & This is an open access article under the CC-BY-SA license \\
\hline
\end{tabular}

\section{A. INTRODUCTION}

One of the most important educational sciences is mathematics. Every level of education is sure to get mathematical subjects. Likewise, colleges also acquire mathematical courses. Mathematics is not a science that is only for its own purposes, but it is a science that is beneficial for most of the other sciences.

Education professionals want to create a learning experience that will ensure the acquisition of knowledge for all students. In today's diverse classrooms, teachers are constantly challenged to distinguish instruction to meet the learning needs of all students, especially those requiring accelerated growth in the areas of mathematical and reading core content. Mathematics is one of the most important subjects in the life of our world. 
Mathematics is a body of knowledge in the fields of science and technology. Mathematics is beautiful and interesting because of symbols, language, terms, technology and others. (Raj Acharya, 2017)

Mathematical abilities are key to be prepared for the 21st century workplace and have caused it increased behaviour in the mathematical standard, (Fazal \& Bryant, 2019). According to Kartikaningtyas et al., in (Masruroh et al., 2020) said mathematics is about thinking, organizing, and also a logic proofing. Because of that, the position of mathematics in education is very beneficial because mathematics is a tool in the education, intelligence and has a significant influence on the development of science and technology.

The generation of students born with digital technology has significant differences in the learning approach. They are used to having access to multiple and instantaneous sources of information, multitasking and connecting socially to each other via mobile devices. The combination of technology, cognitive and social for the new generation needs to be digitally enhanced, this requires new skills to foster a learning concept (Uzunboylu et al., 2011). In learning mathematics students are required to change abstract concepts to be more concrete and understand while working on them. The role of education that is supported by technology is a combination of learning that helps students not only be able to concrete abstract concepts but also facilitate configuration in students' minds (Persico \& Pozzi, 2011)

At STMIK STIKOM Indonesia is one of the technology-based colleges which for the basic course there is a mathematics course that must be taken by every student. College courses are also difficult for students. In line with the research (Núñez-Peña et al., 2013)as a teacher in the course we noted many students experienced failure in achieving educational objectives because it felt emotional and unable to complete mathematical tasks. While according to(Heo \& Chun, 2016) students who often get negative local influences when they face frustration and anxiety during the problem solving process usually the student cannot follow the learning process such as asking, presenting ideas and less communicating.

Based on the results of the interview with the mathematics lecturer stated that the concept of understanding the knowledge of mathematics is still relatively low, there are still many students who are afraid to learn mathematics. This led to the outcome of learning mathematics is still below the value of submission. While the results of interviews with the students who have taken the mathematics study because of the understanding of concepts that are less expressed as follows (1) The learning process with the method of lecture still dominates which still focuses on student centred. This causes students to get bored while learning, (2) The use of technology for the delivery of the material so that the embarrassment or not be able to follow the course directly do not get detailed teaching material explanation, (3) Limited course time also make the interest of difficulties and delays in obtaining information, (4) The knowledge of educators to learn the learning style of students, because each of the students have different learning styles, this affects the learning desires and outcomes. This also found in the study of (Pravita Ayu \& Armiati, 2019) students stating mathematics is a boring lesson, because there are many formulas to understand and training questions often unrelated to their membership program so that students think math is not important to learn.

In studying mathematics, students not only rely on what is being taught, but also how mathematics is taught, or how students learn in learning. Basically, learning is a process of interaction, communication and negotiation between teachers and students. The process of communication is not always running smoothly even the communication process can lead to misunderstandings or misconceptions. For that, lecturers are expected to provide an alternative learning for the students to understand the concepts that have been given not only in the classroom but the student can study anywhere and anytime. Therefore, in the need of computer technology and internet in every learning to make it easier for students to get 
information widest. Blended learning strategy is a learning that integrates traditional face-toface learning and computer-based learning (online and offline) as well as a wide range of communication options that teachers and students can use. Blended learning which combines online learning with traditional face-to-face classroom instruction is currently held in high regard. In elementary schools, science and technology education aims to help children use technology tools and to learn how disciplines such as math and science are relevant to engineering (Hwang et al., 2019)

There are some definitions of what so called blended learning. One of them argues that blended learning is applied using various multi-media applied in an ideal way to solve problems (Keshta, 2013). While according to (Zainuddin \& Attaran, 2016) blended learning is one of the methods of learning in the knowledge age, where teachers take a role as facilitators, motivators, mentors, and consultants Teachers also play a role as 'classmates' where they share ideas and share knowledge with students. This Blended or Hybrid method emphasizes students to learn openly, flexible as needed, critically to solve problems, orientate the empirical world with real action through experiential learning. In blended learning the main focus is students. Students are independent at any given time and are responsible for their studies. Here the lecturer serves as the facilitator to straighten the misconceptions of the students. With these activities, the students can associate the knowledge they acquire to solve more complex problems that can communicate to lecturers or other students. Many online media can be used to communicate with the students. One of the media used to communicate on the learning of blended learning with the students is telegram. Telegram, as one of the most favoured social networking sites, has millions of users from primary schools to universities. On Telegram, people from all ages can create their own profiles, chat with each other and share their favourite photos and videos. It also has applications useful for teaching and learning. It is also a technological tool which can nurture the student-teacher relationship by creating positive learning experiences for both parties Cooperative Learning (Aghajani \& Adloo, 2018). According to (Winarto \& Hardyanto, 2019) with the development of information technology will enable activities to be done quickly, precisely and accurately, thereby, resulting in high productivity. The learning process that is supported with information technology will be more effective when accompanied by technology or tools to convey information called as learning media. This is in line with the research by (Shelton \& Parlin, 2016) the results of his research can help inform the designers of educational technology by connecting class instructors with children by creating advanced mobile apps.

Blended learning is reviewed from a variety of student learning styles, where each student has different learning styles. According to (Apipah et al., 2018) the learning style of a person determines how the student can absorb something through its senses between its senses, which sense is more developed during the learning process. According to (Aljaberi, 2015) in his research concluded students ability to solve mathematical problems varies depending on the learning style. The most frequently preferred learning style was Activist-Reflector style, which showed better performance in solving math problems than other styles. According to (Keliat, 2016) learning style is one of the important factors that can affect student's academic achievement, but nowadays the application of learning style that suits student's ability is often forgotten.

Including e-learning in face-to-face learning will have a positive impact on students. This is in line with reasoning mind research which has included e-learning principles of personalization, modality, and redundancy into the design of a mixed learning platform called Genie 3, which concludes that the level of student involvement is much higher than traditional classrooms (Mulqueeny et al., 2015). In a blended learning environment resulted in a significant difference to the student's academic achievement in the experimental class, (Ceylan \& Elitok Kesici, 2017). This is in line with the research conducted by (Darma et al., 
2020) stating blended learning can be one of the alternative and effective strategies especially for teaching mathematics in college. An innovation of mathematical learning with the ultimate goal of providing opportunities for various characteristics in order to process self-learning, sustainable, lifelong learning so that learning will be effective, more efficient, interesting and enjoyable. Similarly, the research conducted by (Zainuddin \& Keumala, 2018)this blended learning method is very relevant to be implemented in Indonesian higher education to support students to learn independently outside the classroom, build the ability to discuss and collaborate with their peer (peer-interaction) to solve problems. In the research of (Wahyuni, 2018) there is a significant effect of blended learning model towards student's writing ability. Research conducted by (Khader, 2016) the results of his research showed a significant difference in statistic post-achievement of the experimental group with the learning of blended learning from its gender. Mathematics subject with blended learning techniques has a positive effect on students' communication skills, problem solving and technology (Kashefi et al., 2013).

Educators always carry out innovations in teaching and learning. The presence and involvement of students is a problem in the classroom and can be overcome with mobile learning as a learning approach. In this sense, telegram is a tool for mobile learning. Telegram can explore both face-to-face and online learning processes. This study found several techniques that telegrams can use: attendance, discussion, drawing, and audio. Students answered that learning by telegram allows them to have new experiences, be more creative and generate authentic ideas without being embarrassed and encourages them to be enthusiastic about learning (H. Iksan \& Mohd Saufian, 2017). The application of the telegram application to find out students' perceptions in improving the teaching and learning process through the link shared in the telegram discussion group is very useful because we don't need a long time to get the feedback. The results showed that the telegram application supports the improvement of the teaching and learning process by providing a fast and easy platform to share information (Perlis et al., 2016)

On this basis, it is deemed necessary to conduct research as an empirical study to test the influence of telegram-assisted blended learning strategies on the results of student mathematics learning by observing student learning style. Thus, the researcher chooses the title: Influence of Blended strategy of Telegram-Assisted Learning Towards Mathematics Learning Results Reviewed from The Learning Style. So the research aimed at the practical contributed to the mathematics education with the description of the influence of the learning impact of telegram-assisted blended lessons on mathematical learning outcomes while theoretically aimed at educators to use the alternative techniques of this telegram-assisted blended learning technique in teaching at all levels of education.

\section{B. METHODS}

This research is a type of quasi-experimental research. According to (Hastjarjo, 2019)Quasi-Experimentation is an experiment where the placement of the smallest unit of the experiment into the experimental and control groups is not done by random (non-random assignment).With a $2 \times 3$ factorial research design. The design referred to in this study is two learning models with a telegraph-assisted blended learning strategy and conventional learning with three categories of student learning styles, namely visual learning styles, audio learning styles and kinaesthetic learning styles in Table 1. 
Table 1. $2 \times 3$ Factorial Design

\begin{tabular}{lccc}
\hline \multirow{2}{*}{ Learning Model } & \multicolumn{3}{c}{ Learning Styles } \\
\cline { 2 - 4 } & $\begin{array}{c}\text { Audio Learning } \\
\text { Styles (Y1) }\end{array}$ & $\begin{array}{c}\text { Visual Learning } \\
\text { Styles (Y2) }\end{array}$ & $\begin{array}{c}\text { Kinaesthetic } \\
\text { learning styles (Y3) }\end{array}$ \\
\hline Conventional Learning Model (A1) & A1Y1 & A1Y2 & A1Y3 \\
\hline $\begin{array}{l}\text { Learning with a telegraph-assisted } \\
\text { blended learning strategy (A2) }\end{array}$ & A2Y1 & A2Y2 & A2Y3 \\
\hline
\end{tabular}

The respondents in this study is the second semester students majoring in informatics engineering at STMIK STIKOM Indonesia campus. Respondents is a generalization area that consists of objects or subjects that have certain qualities and characteristics determined by research to be studied and then drawn conclusions Sugiyono in (Ekayanti et al., 2019). The sampling procedure in this study is a random sampling technique that begins by carrying out the equivalence test of 4 classes taken using the final mathematical value 1 with ANOVA test one-way assisted by SPSS 2.0 for Windows. Based on the analysis of one way ANOVA, the value of $F=2,446$ and sig number are obtained. 0.067 more than $\alpha=0.05$.This means that the ability of students from these 4 classes is of equal ability. After that randomly selected, as an experimental group and as a control group. For two classes as a control group with the treatment of the application of conventional learning (learning system applied from the STMIK STIKOM Indonesia campus) and the next two classes for the experimental group with the treatment of the application of a telegram-assisted blended learning strategy. The independent variable in this study is a telegram-assisted blended learning strategy. The controlling variable in this study is the mathematics learning style. While the dependent variable mathematics student learning outcomes. The data that will be sought in this study are the score of student mathematics learning outcomes and student learning styles which will be measured using a questionnaire. Previously the questionnaire would be tested for validity and reliability. To determine the validity of the content carried out by experts. Instruments that have been assessed by experts will then be trialled in the field. The purpose of testing this instrument is to determine the validity of the questionnaire items and the reliability of the instrument. After that, the score data of student mathematics learning outcomes and student learning style scores will be analysed descriptively. To test the hypothesis, it will be analysed by two-way analysis of variance with the F-test and then will be further tested with the SPSS-assisted Scheffe Test 25.0 for Windows. The hypotheses that will be tested in this study are (1) Student learning outcomes in mathematics following telegramassisted blended learning strategies are better than student learning outcomes in mathematics following conventional learning, (2) The effect of telegraph-assisted blended learning strategies on student mathematics learning outcomes on learning styles.

\section{RESULT AND DISCUSSION}

Based on data processing with description analysis, it is obtained the recapitulation of the score calculation results of students learning mathematics as shown in Table 2 and Table 3.

Table 2.Recapitulation of Mathematics Learning Outcomes Calculation Results for Students

\begin{tabular}{lccccc}
\hline & A1 & A2 & Y1 & Y2 & Y3 \\
\hline $\mathrm{N}$ & 60 & 60 & 39 & 61 & 20 \\
\hline Mean & 69,87 & 78,80 & 73,72 & 73,28 & 78,75 \\
\hline Median & 70,00 & 77,00 & 73,00 & 73,00 & 80,00 \\
\hline Mode & 70 & $77^{\mathrm{a}}$ & 77 & 80 & $80^{\mathrm{a}}$ \\
\hline Std Deviation & 11,936 & 12,119 & 14,329 & 11,125 & 14,075 \\
\hline
\end{tabular}




\begin{tabular}{lccccc}
\hline & A1 & A2 & Y1 & Y2 & Y3 \\
\hline Varian & 142,456 & 146,875 & 205,313 & 123,771 & 198,092 \\
\hline Range & 46 & 50 & 50 & 50 & 50 \\
\hline Minimum & 47 & 47 & 47 & 47 & 47 \\
\hline Maximum & 93 & 97 & 97 & 97 & 97 \\
\hline Total & 4192 & 4728 & 2875 & 4470 & 1575 \\
\hline
\end{tabular}

Table 3. Recapitulation of Mathematics Learning Outcomes Calculation Results for Students (Cont'd)

\begin{tabular}{lrrrrrr}
\hline & A1Y1 & A1Y2 & A1Y3 & A2Y1 & A2Y2 & \multicolumn{1}{c}{ A2Y3 } \\
\hline $\mathrm{N}$ & 14 & 34 & 12 & 25 & 27 & 8 \\
\hline Mean & 64,14 & 71,38 & 72,25 & 79,08 & 75,67 & 88,50 \\
\hline Median & 67,00 & 73,00 & 75,00 & 77,00 & 77,00 & 92,00 \\
\hline Mode & 70 & 70 & 80 & 77 & 80 & 97 \\
\hline Std Deviation & 12,440 & 10,990 & 12,800 & 12,563 & 11,031 & 9,957 \\
\hline Varian & 154,747 & 120,789 & 163,841 & 157,827 & 121,692 & 99,143 \\
\hline Range & 43 & 43 & 46 & 50 & 40 & 24 \\
\hline Minimum & 47 & 47 & 47 & 47 & 57 & 73 \\
\hline Maximum & 90 & 90 & 93 & 97 & 97 & 97 \\
\hline Total & 898 & 2427 & 867 & 1977 & 2043 & 708 \\
\hline
\end{tabular}

Explanation :

A1 = Student math test scores with conventional learning method

A2 = Student math test scores with blended learning method by telegram

Y1 = Student math test scores with an audio learning style

Y2 = Student math test scores with a visual learning style

Y3 = Student math test scores with a kinesthetic learning style

A1Y1 = Student math test scores with conventional learning methods that have an audio learning style

A1Y2 = Student math test scores with conventional learning methods that have a visual learning style

$\mathrm{A} 1 \mathrm{Y} 3=$ Student math test scores with conventional learning methods that have a kinesthetic learning style

A2Y1 = Student math test scores with blended learning methods that have an audio learning style

A2Y2 = Student math test scores with blended learning methods that have a visual learning style

$\mathrm{A} 2 \mathrm{Y3}=$ Student math test scores with blended learning methods that have $\mathrm{a}$ kinesthetic learning style

Descriptive analysis of class data with conventional learning and blended learning strategy assisted by telegram, obtained the results that the conventional class (A1) has an average value of mathematics learning outcomes median 69.87 and mode 70.00 . The standard deviation of mathematics learning outcomes for classes with conventional learning is 11,936. This shows a fairly large spread of values with a variance of 142,456 . The lowest mathematics learning outcomes in this class are 47 while the highest score is 93. On the other hand, the class with telegram-assisted blended learning strategy (A2) has an average math test that is higher than the conventional class of 78.80 with a median and 77.00 mode. The standard deviation in this class shows the quite large distribution of student learning outcomes in mathematics with a value of 12.119 and a variance of 146.875.The lowest learning outcomes 
obtained by students with telegram-assisted blended learning strategies by 47 while the highest value is 97.

Besides being seen from the learning strategy, differences in mathematics learning outcomes are also seen from the learning styles of students. There are three student learning styles, namely Audio, Visual, and Kinesthetic. The group of students who have Audio learning styles are 39 students. The group with this learning style has an average mathematical learning outcome of 73.72 with a mean value of 73.00 and mode 77 . The distribution of data in this data group is quite large with a standard deviation of 14,329 and a variance of 205,313. Students in this group had the lowest learning outcomes 47 and the highest score 97 . The group of students with a visual learning style of 61 people had an average score of a math test of 73.28 with a median value of 73 and a mode of 80 . A standard deviation of 11.125 indicates sufficient data distribution big among students. Students with visual learning styles have the lowest learning outcomes 47 and the highest 97. The third learning style is kinesthetic. This group of students with learning styles totals 20 students. The average value of the mathematics test in this group is greatest when compared to the average test in the group of students with other learning styles, which is 78.75 with a median and 80 mode. The distribution of data in this group is quite large, marked by the standard value deviation of 14,075 and variance of 198,092 . The lowest score in this group of students is 47 and the highest is 97.

Differences are also viewed from the combination of conventional learning and telegramassisted blended learning with student learning styles (audio, visual, and kinesthetic). The results of the descriptive analysis showed that students who were given conventional learning with audio learning styles (A1Y1) of 14 people had an average mathematics test of 64.14 with a median value of 67 and mode 70 . The distribution of data in this group was quite large, marked by grades standard deviation of 12,440 and variance 157,747. The lowest learning outcomes in this group are 47 and the highest is 90 . The group of students who are conventional learning with visual learning styles (A1Y2) as many as 34 people have an average mathematics test of 71.38 with a median value of 73 and mode 70 . The distribution of data in this group quite large, marked by a standard deviation of 10.990 and a variance of 120.789. The lowest learning outcomes in this group are 47 and the highest is 90.

While the group of students who were given conventional learning with kinesthetic learning styles (A1Y3) as many as 12 people had an average of 72.25 math tests with a median value of 75 and mode 80 . The distribution of data in this group was quite large, marked by a standard deviation of 12,800 and variance 163,841 . The lowest learning outcomes in this group are 47 and the highest is 93.

The group of students who were given a telegram-aided blended learning strategy and had an audio learning style (A2Y1) of 25 students. The average value of the mathematics test in this group was 79.08 with a median value and mode 77 . The standard deviation of 12.563 and the variance of 157.827 showed a large spread of data in this group. In this group the lowest mathematics learning outcomes were 47 and the highest was 97 . The group of students who were given a telegram-assisted blended learning strategy and had a visual learning style (A2Y2) were 27 students. The average value of the mathematics test in this group was 75.67 with a median value of 77 and mode 80 . The standard deviation of 11.031 and the variance of 121.692 showed a large spread of data in this group. In this group the lowest mathematics learning outcomes are 57 and the highest is 97.

While the group of students who were given a telegram-aided blended learning strategy and had a kinesthetic learning style (A2Y3) were 8 students. The average value of the mathematics test in this group was the largest compared to the other groups, namely 88.50 with a mean value of 92 and mode 97. Standard deviation of 9.957 and variance of 99.143 showed a large spread of data in this group but the smallest when compared with the group 
another. In this group the lowest mathematics learning outcomes were 73 and the highest was 97.

Normality testing is performed by the Kolmogorov-Smirnov test with the help of SPSS Software for Windows version 25.0. The test results show the Kolmogorov-Smirnov value of 0.074 with a Significance value of 0.156 . Significance values of more than 0.05 indicate that the data are normally distributed so that the normality assumptions in the ANOVA model have been met so that all data on the mathematics learning outcomes of students are normally distributed. Testing the homogeneity of variance in this study was carried out using the Levene's Test for Equality of Variances. The significance value of the Levene test results indicates a value greater than 0.05 so that it can be said that the variance of each group is the same, or in other words each group is said to be homogeneous. Therefore, the assumption of the variance homegenity of the ANOVA model has been fulfilled. So that both groups have homogeneous variants.

Hypothesis testing in this study uses two-way analysis of variance (ANOVA), and then will be further tested by the Scheffe Test. With the help of SPSS 25.0 results obtained as shown in the summary results of data analysis of mathematical learning motivation with analysis of variance (ANOVA) of the two paths as in Table 4.

Table 4. ANOVA Summary Two Lines of Learning Outcomes For All Treatments

\begin{tabular}{llllll}
\hline $\begin{array}{c}\text { Variant } \\
\text { resources }\end{array}$ & \multicolumn{1}{c}{ DF } & \multicolumn{1}{c}{ Mean Square } & \multicolumn{1}{c}{ F count } & Significant & Explanation \\
\hline Inter A & 1 & 3257,870 & 24,045 & 0,000 & Significant \\
\hline Inter Y & 2 & 499,077 & 3,684 & 0,028 & Significant \\
\hline Inter A*Y & 2 & 466570 & 3,296 & 0,041 & Significant \\
\hline Intercept & 1 & 526709,203 & 3887,446 & - & - \\
\hline Total & 6 & - & - & - & - \\
\hline
\end{tabular}

For hypothesis 1 the test statistic used to test this hypothesis is the F test in a two-way analysis of variance. The null hypothesis ( $\mathrm{H0}$ ) will be rejected if the value of Fcount> F table or if the significance is <alpha (0.05). If viewed from the previous table, the source of the diversity of the Strategy obtained a Fcount value of 24.045 and a significance value of 0.000 . Significance value of less than 0.05 results in $\mathrm{H} 0$ being rejected and $\mathrm{H} 1$ accepted so that it can be concluded that the mathematics learning outcomes of students who are given conventional learning are significantly different from students who are given telegram-assisted blended learning strategies. This means that the mathematics learning outcomes of students who take telegram-assisted blended learning strategies are better than those of students who take conventional learning. When viewed from the average value of students' math tests, the group of students who were given conventional learning had an average test score of 69.87 while the group of students who were given a telegram-assisted blended learning strategy had an average test score of 78.80. This shows that the group of students who were given a telegramassisted blended learning strategy was superior to the group of students who were given conventional learning. The low learning outcomes in conventional learning may be due to lack of variation in the learning process so that the information obtained is less than optimal.

In the application of blended learning assisted by telegram, students can participate in learning in accordance with their respective learning styles. Students can easily carry out discussions together with their friends or with lecturers and teaching materials that are not yet understood can be studied conventionally or assisted by telegrams. Even though conventional learning both obtain material in Google classroom but teaching and learning activities are still less effective because students lack communication and discussion with friends or lecturers so that the material provided is still not optimal for understanding which 
has an impact on learning outcomes. Thus the results of student mathematics learning that are taught with telegram-assisted blended learning strategies are better than conventional mathematics learning outcomes of students who are taught. This is consistent with the results of research conducted by (Lin et al., 2017) preliminary results indicated that male students and high-ability students were more motivated in the blended learning environment. Students gave positive feedback on the use of the Moodle learning platform for mathematics after experiencing blended learning. While research conducted by (Setiadi et al., 2016) produced The development of this blended learning-based self-learning can improve teacher's performance in conducting classroom action research and enhance their abilities in compiling the research report. Blended learning maybe one of the most suitable solutions for Indonesian teachers who haven't joined the training and haven't conducted the research. They don't only need the training but also need the facilitator to guide them to conduct the research. Using blended learning can motivate self-directed learning and enhance the research skills.

In the second hypothesis testing, the test statistic used to test this hypothesis is the F test in a two-way analysis of variance. The null hypothesis (HO) will be rejected if the value of Fcount $>\mathrm{F}$ table or if the significance is <alpha (0.05). If viewed from the previous table, the source of the diversity of Learning Styles obtained a Fcount value of 3.684 and a significance value of 0.028 . Significance value of less than 0.05 results in $\mathrm{HO}$ being rejected and $\mathrm{H} 1$ accepted so that it can be concluded that student learning styles affect student mathematics learning outcomes. Furthermore, a double comparison test was performed with the Scheffe Test. From the test results obtained that there is no pair of learning styles that produce significantly different student learning outcomes in mathematics. It can be concluded that if only in terms of learning styles, student mathematics learning outcomes are not significantly different. In the application of telegram-assisted blended learning, students can participate in learning in accordance with their respective learning styles. Students can get information in various ways. One of them is by using the telegram application. From the application, students are given features for material and discussion forums, by searching for broader information through online media, as well as through offline media.Thus telegram-assisted blended learning has an influence on student mathematics learning outcomes in visual, audio, and kinesthetic learning styles.

In line with the results of research conducted by(Putri \& Suryati, 2020), based on the research results it is known that the students of the Computer System Study Program in 2019 have a tendency towards kinesthetic learning styles. From 124 students, it was found that 13\% Visual, 35\% Auditorial, 42\% Kinesthetic, 3\% Combined Visual and Auditorial, 5\% Combined Visual and Kinesthetic, and 2\% Combined Auditorial and Kinesthetic.According to (Pradnyawati \& Suparta, 2014) student's motivation to learn mathematics taught by cooperative learning assisted by blended learning strategies is better than student motivation to learn mathematics by cooperative learning in visual, auditory, and kinesthetic learning styles. While the research of (Burhendi et al., 2020) the implementation of Blended Learning to use Discovery Learning Method in the Calculus I Course still needs to be improved in terms of information systems, and the selection of teaching methods must be considered so that the learning the process with the blended learning model can take place appropriately.

\section{CONCLUSION AND SUGGESTIONS}

Based on the analysis of the discussion as described in the previous section, it can be concluded several things as follows: (1) The results of mathematics learning students who are given conventional learning are significantly different from students who are given telegramassisted blended learning strategies. This means that the mathematics learning outcomes of students who take telegram-assisted blended learning strategies are better than those of 
students who take conventional learning, (2) The influence of telegraph-assisted blended learning strategies on student mathematics learning outcomes in visual, audio, kinesthetic learning styles. Furthermore, a double comparison test with the Scheffe Test. From the test results obtained that there is no pair of learning styles that produce significantly different student learning outcomes in mathematics. It can be concluded that if only in terms of learning styles, student mathematics learning outcomes are not significantly different. Conventional learning becomes learning that is adjusted to the provisions of the educational institution. Based on the results of the research that has been done, there are some suggestions from researchers for lecturers or educators to use this strategy in the learning process using a telegram-assisted blended learning strategy and pay attention to the learning styles of their students so that we can choose the right method of learning and for researchers to have research this can be used as a reference to redevelop this research to be even better. Because this research was taken during the corona virus pandemic.

\section{ACKNOWLEDGEMENT}

The author would like to thank all those who have helped in this research process. Especially to the Directorate of Research and Technology Research and Technology for beginner lecturer research funding and LPPM STIMK STIKOM Indonesia who always provide support and information. And STIMK STIKOM Indonesia students who are willing to be part of this research.

\section{REFERENCES}

Aghajani, M., \& Adloo, M. (2018). The effect of online cooperative learning on students' writing skills and attitudes through telegram application. International Journal of Instruction. Vol. 11(3):433448. https://doi.org/10.12973/iji.2018.11330a

Aljaberi, N. M. (2015). University Students' Learning Styles and Their Ability to Solve Mathematical Problems. International Journal of Business and Social Science. Vol. 6, No. 4(1).

Apipah, S., Kartono, \& Isnarto. (2018). An analysis of mathematical connection ability based on student learning style on visualization auditory kinesthetic (VAK) learning model with self-assessment. Journal of Physics: Conference Series 983. https://doi.org/10.1088/1742-6596/983/1/012138

Burhendi, F. C. A., Abdurrozak, A., \& Soenarto, S. (2020). The implementation of blended learning models based liveboard against affective aspects in modern physics course. Gravity: Jurnal Ilmiah Penelitian Dan Pembelajaran Fisika. Vol. 6(1):1-6. https://doi.org/10.30870/gravity.v6i1.7106

Ceylan, V. K., \& Elitok Kesici, A. (2017). Effect of blended learning to academic achievement. Journal of Human Sciences. Vol.14(1). https://doi.org/10.14687/jhs.v14i1.4141

Darma, I. K., Karma, I. G. M., \& Santiana, I. M. A. (2020). Blended Learning, Inovasi Strategi Pembelajaran Matematika di Era Revolusi Industri 4 . 0 Bagi Pendidikan Tinggi. Prosiding Seminar Nasional Pendidikan Matematika. 527-539

Ekayanti, N. L. P., Darsana, I. W., \& Sujana, I. W. (2019). Pengaruh Model Pembelajaran Mind Mappig Berbantuan Media Audio-Visual Terhadap Kompetensi Pengetahuan IPS. Media Komunikasi FPIPS. Vol. 18 (2). https://doi.org/10.23887/mkfis.v18i2.22241

Fazal, M., \& Bryant, M. (2019). Blended Learning in Middle School Math: The Question of Effectiveness. In Journal of Online Learning Research. Vol. 5(1): 49-64.

H. Iksan, Z., \& Mohd Saufian, S. (2017). Mobile Learning: Innovation in Teaching and Learning using Telegram. IJPTE: International Journal of Pedagogy and Teacher Education. Vol. 1(1). https://doi.org/10.20961/ijpte.v1i1.5120

Hastjarjo, T. D. (2019). Rancangan Eksperimen-Kuasi. Buletin Psikologi. Vol. 27(2). https://doi.org/10.22146/buletinpsikologi.38619

Heo, H. J., \& Chun, B. A. (2016). A study on the effects of mobile-based LMS on flipped learning: Focused on the affective pathway in pre-service teacher education. International Journal of Software Engineering and Its Applications. Vol. 10(12):473-484 
https://doi.org/10.14257/ijseia.2016.10.12.39

Hwang, R. H., Lin, H. T., Sun, J. C. Y., \& Wu, J. J. (2019). Improving learning achievement in science education for elementary school students via blended learning. International Journal of Online Pedagogy and Course Design. Vol. 9(2):44-62. https://doi.org/10.4018/IJOPCD.2019040104

Kashefi, H., Ismail, Z., Mohammadyusof, Y., \& Mirzaei, F. (2013). Generic skills in engineering mathematics through blended learning: A mathematical thinking approach. International Journal of Engineering Education. Vol. 9(5):1-16.

Keliat, N. R. (2016). The Profile of Students' Learning Styles and Their Effects on Grade Point Average (GPA) Achievement. Edutech. Vol. 15(2). https://doi.org/10.17509/edutech.v15i2.4069

Keshta, A. S. (2013). The Effectiveness of a Blended Learning Program on Developing Palestinian Tenth Graders' English Writing Skills. Education Journal. Vol. 2(6): 208-221. https://doi.org/10.11648/j.edu.20130206.12

Khader, N. S. K. (2016). The Effectiveness of Blended Learning in Improving Students' Achievement in Third Grade's Science in Bani Kenana. Journal of Education and Practice. Vol. 7(35).

Lin, Y. W., Tseng, C. L., \& Chiang, P. J. (2017). The effect of blended learning in mathematics course. Eurasia Journal of Mathematics, Science and Technology Education. Vol. 13(3):741-770. https://doi.org/10.12973/eurasia.2017.00641a

Masruroh, A. A., Oktaviani, R., Kulsum, S. I., \& Afrilianto, M. (2020). Learning Mathematics with Contextual Approach to Improve Outcomes Learning Maths in Vocational High School. JTAM / Jurnal Teori Dan Aplikasi Matematika. Vol. 4(1):56-63. https://doi.org/10.31764/jtam.v4i1.1870

Mulqueeny, K., Kostyuk, V., Baker, R. S., \& Ocumpaugh, J. (2015). Incorporating effective e-learning principles to improve student engagement in middle-school mathematics. International Journal of STEM Education. Vol. 2(1). https://doi.org/10.1186/s40594-015-0028-6

Núñez-Peña, M. I., Suárez-Pellicioni, M., \& Bono, R. (2013). Effects of math anxiety on student success in higher education. International Journal of Educational Research. https://doi.org/10.1016/j.ijer.2012.12.004

Perlis, U., Nizam, M., Ibrahim, B., Norsaal, E. B., Hanapiah, M., Abdullah, B., Hisham, Z., Che, B., \& Othman, A. Bin. (2016). Teaching and learning enhancement based on telegram social media tool. Jurnal Intelek, Vol. 11(1):7-11.

Persico, D., \& Pozzi, F. (2011). Task, Team and Time to structure online collaboration in learning environments. World Journal on Educational Technology. Vol. 3(1): 1-15.

Pradnyawati, L., \& Suparta, M. (2014). Pengaruh Strategi Blended Learning Dalam Pembelajaran Kooperatif Terhadap Motivasi Belajar Matematika Ditinjau Dari Gaya Belajar Siswa di SMPK 2 Harapan. Jurnal Jurusan Pendidikan Matematika Ganesha.

Pravita Ayu, W., \& Armiati. (2019). Analysis introduction of the development of mathematics learning device based of professional competency in electrical engineering programs vocational high school class X. Journal of Physics: Conference Series. https://doi.org/10.1088/1742$6596 / 1317 / 1 / 012136$

Putri, N. W. S., \& Suryati, N. K. (2020). Analysis of The Style of Learning Based on Visual, Auditorial, Kinesthetic on Students of Computer System. IJECA (International Journal of Education and Curriculum Application). Vol. 3(1). https://doi.org/10.31764/ijeca.v3i1.2056

Raj Acharya, B. (2017). Factors Affecting Difficulties in Learning Mathematics by Mathematics Learners. International Journal of Elementary Education, Vol. 6(2):8-15. https://doi.org/10.11648/j.ijeedu.20170602.11

Setiadi, G., Joyoatmojo, S., \& Sajidan, S. (2016). the Development of Blended Learning-Based SelfLearning on Classroom Action Research Training Material To Improve Teachers Professionalism. International Journal of Education and Research. Vol. 2(1).

Shelton, B. E., \& Parlin, M. A. (2016). Teaching Math to Deaf/Hard-of-Hearing (DHH) Children Using Mobile Games: Outcomes with Student and Teacher Perspectives. International Journal of Mobile and Blended Learning. Vol. 8(1):1-17. https://doi.org/10.4018/IJMBL.2016010101

Uzunboylu, H., Bicen, H., \& Cavus, N. (2011). The efficient virtual learning environment: A case study of web 2.0 tools and Windows live spaces. Computers and Education. Vol. 56(3): 720-726. https://doi.org/10.1016/j.compedu.2010.10.014

Wahyuni, S. (2018). The Effect of Blended Learning Model towards Students' Writing Ability. J-SHMIC : 
Journal of English for Academic. https://doi.org/10.25299/jshmic.2018.vol5(2).1801

Winarto, A., \& Hardyanto, W. (2019). Telegram Development in Dokeos-Based E-Learning As a Learning Media to Improve Students' Motivation in Learning Physics. Telegram Development in Dokeos-Based E-Learning As a Learning Media to Improve Students' Motivation in Learning Physics. Vol. 3(37):78-85. https://doi.org/10.15294/physcomm.v0i0.20628

Zainuddin, Z., \& Attaran, M. (2016). Malaysian students' perceptions of flipped classroom: a case study. Innovations in Education and Teaching International. Vol. 53(6):660-670. https://doi.org/10.1080/14703297.2015.1102079

Zainuddin, Z., \& Keumala, C. M. (2018). Blended Learning Method Within Indonesian Higher Education Institutions. Jurnal Pendidikan Humaniora.Vol. 6(2):69-77. 